\title{
PARTIAL TEARS OF THE ANTERIOR CRUCIATE LIGAMENT
}

\author{
PROGRESSION TO COMPLETE LIGAMENT DEFICIENCY
}

\author{
FRANK R. NOYES, LISA A. MOOAR, CLAUDE T. MOORMAN III, GEORGE H. MCGINNISS
}

From Cincinnati Sportsmedicine Center and the Deaconess Hospital, Ohio

\begin{abstract}
In a prospective seven-year study, we treated 32 patients with partial ruptures of the anterior cruciate ligament (ACL) verified by arthroscopy. Twelve knees $(38 \%)$ progressed to complete ACL deficiency with positive pivot shift tests and increased anteroposterior translation on tests with the KT-1000 arthrometer. Patients with partial ACL tears frequently had limitation for strenuous sports, while those developing ACL deficiency had additional functional limitations involving recreational activities.

Three factors were statistically significant in predicting which partial tears would develop complete ACL deficiency: the amount of ligament tearing - one-fourth tears infrequently progressed, one-half tears progressed in $50 \%$ and three-fourth tears in $86 \%$; a subtle increase in initial anterior translation; and the occurrence of a subsequent re-injury with giving-way.
\end{abstract}

In 1976 we established guidelines for the arthroscopic evaluation of patients with acute traumatic haemarthrosis and in 1980, we reported the incidence of complete and partial rupture of the anterior cruciate ligament $(A C L)$ and the frequently associated injuries to menisci, articular cartilage, and to other ligamentous structures (Noyes et al 1980). Patients with partial ACL tears were given a rehabilitation programme and then followed-up. These and subsequent patients form the basis of this report.

Partial ACL tears have been recognised for many years (Liljedahl, Lindvall and Wetterfors 1965; Bassett 1972; McDaniel and Dameron 1980, 1983; DeHaven 1983). Small series of patients have been reported (McDaniel 1976; Noyes et al 1980; Monaco, Noble and Bachman 1982; Farquharson-Roberts and Osborne 1983; Lucie, Wiedel and Messner 1984) but only one other long-term study (Odensten, Lysholm and Gillquist 1985) has been reported to date. That study differs from ours in that about half of the knees also had other knee ligaments injured and repaired. We have excluded knees with other ligament injuries or operations which could affect the functional outcome of a partial ACL tear.

F. R. Noyes, MD

L. A. Mooar, BA

C. T. Moorman III, MD

G. H. McGinniss, MD

Cincinnati Sportsmedicine Research Department, Deaconess Hospital,

311 Straight Street, Cincinnati, Ohio 45219, USA.

Correspondence should be sent to Dr F. R. Noyes.

(C) 1989 British Editorial Society of Bone and Joint Surgery

$0301-620 \mathrm{X} / 89 / 5168 \$ 2.00$

J Bone Joint Surg [ Br] 1989;71-B:825-33.
We aimed to determine the long-term functional limitations of patients after a partial ACL tear and to discover the frequency of progression to complete ACL deficiency and the factors involved.

\section{PATIENTS AND METHODS}

Criteria. During a 7.3 year period from 1976 to 1983 , we made the arthroscopic diagnosis of acute partial ACL tears in 38 patients. In all cases, the remaining intact portion of the ACL was observed to become tense on attempted movement and to resist anterior tibial translation. We excluded tears involving more than $75 \%$ of the ligament, in which only a few major fibre bundles were intact. All our cases had a negative pivot shift and were evaluated within six weeks of injury. None had a prior history of knee injury and all were treated by one surgeon (FRN).

Of the 38 patients, 32 returned for follow-up evaluation $(84 \%)$, the others being unable to attend or lost to follow-up. At injury, their ages ranged from 14 to 38 years (average 21.4); 28 were male and four female. The injury was to the right knee in 15 patients and to the left in 17. Typically, the patients were very active; 24 were involved in fully competitive sports on four to seven days per week; five in major recreational sports one to three times per week; and three in light recreational sports.

Mechanism of injury. Injury had occurred most frequently during American football (31\%), basketball (16\%), and baseball or softball (13\%). In 26 patients, a non-contact event involving twisting, turning, or jumping caused the 
injury, and 20 patients $(62 \%)$ had felt or heard a pop at the time. An acute haemarthrosis, with swelling within 24 hours, had occurred in 30 knees $(94 \%)$. Twenty-six patients were unable to continue their sports or activity, four had continued with mild difficulty, and two had continued without problems.

Initial examination. All patients were examined under anaesthesia and graded using the system we have previously described (Noyes et al 1983a,b; Noyes and Grood 1987). For the pivot shift test, grade III denotes the classical phenomenon and, in the scoring in Table I, this is shown by an increase in two grades over the opposite normal knee (grade I). If the unaffected knee had physiologically lax ligaments, a one grade increase is shown (from a grade II normal knee). All knees that progressed to ACL deficiency are noted by a hash mark in Table $\mathrm{I}$.

Anterior cruciate disruption. Arthroscopic evaluation was performed at an average of 14 days after injury (Table I). An anteromedial portal was used to visualise the femoral attachment of the anterior cruciate ligament. Using a nerve hook, we carefully probed the ligament and removed overlying synovium. The injury to the ligament was recorded by: the region of the tear (proximal, middle-

Table I. Details of 32 patients with partial tears of an ACL

\begin{tabular}{|c|c|c|c|c|c|c|c|c|c|c|c|c|c|c|c|}
\hline \multirow[b]{2}{*}{ Case } & \multirow[b]{2}{*}{$\begin{array}{l}\text { Agel } \\
\text { Sex }\end{array}$} & \multirow[b]{2}{*}{$\begin{array}{l}\text { Follow-up } \\
\text { (months) }\end{array}$} & \multirow[b]{2}{*}{$\begin{array}{l}\text { Mechanism of } \\
\text { injury }\end{array}$} & \multirow{2}{*}{$\begin{array}{l}\text { Time from } \\
\text { injury to } \\
\text { arthroscopy } \\
\text { (days) }\end{array}$} & \multirow{2}{*}{$\begin{array}{l}\text { Estimated } \\
\text { ACL } \\
\text { disruption" }\end{array}$} & \multirow{2}{*}{ Meniscit } & \multirow{2}{*}{$\begin{array}{l}\text { Tibio } \\
\text { femoral } \\
\text { articular } \\
\text { surfaces: }\end{array}$} & \multirow[b]{2}{*}{$\begin{array}{l}\text { Patellar } \\
\text { surfaces }\end{array}$} & \multicolumn{3}{|c|}{ Instability§ (initial follow-up) } & \multirow{2}{*}{$\begin{array}{l}\text { Difference } \\
\text { in KT-1000 } \\
\text { displacement } \\
\text { (mm) }\end{array}$} & \multirow[b]{2}{*}{$\begin{array}{l}\text { Post-op } \\
\text { cast }\end{array}$} & \multirow[b]{2}{*}{$\begin{array}{l}\text { Pignificant } \\
\text { re-injuries }\end{array}$} & \multirow{2}{*}{$\begin{array}{l}\text { Additioaal } \\
\text { surgical } \\
\text { procedures }\end{array}$} \\
\hline & & & & & & & & & Lachman & $\begin{array}{l}\text { Pivot } \\
\text { shift }\end{array}$ & Lateral & & & & \\
\hline 1 & $14 \mathrm{M}$ & 99 & $\begin{array}{l}\text { Football } \\
\text { contact }\end{array}$ & 25 & 25 Prox & L-incomplete & $\mathbf{N}$ & $\mathbf{N}$ & $1 / 0$ & $1 / 0$ & $0 / 0$ & - & Yes & 0 & None \\
\hline 2 & $14 \mathrm{M}$ & 56 & $\begin{array}{l}\text { Basketball } \\
\text { valgus twist }\end{array}$ & 5 & $\underset{P x}{25} \mathrm{~A}, \mathrm{M}$ & $N$ & $\mathbf{N}$ & $\mathbf{N}$ & $1 / 1$ & $1 / 1$ & $0 / 0$ & 3.75 & Yes & 0 & None \\
\hline 3 & $17 \mathrm{M}$ & 80 & $\begin{array}{l}\text { Body surfing } \\
\text { contact }\end{array}$ & 9 & IH A. D & $N$ & $\mathbf{N}$ & Softening & $0 / 0$ & $0 / 0$ & $0 / 0$ & -0.50 & No & 0 & None \\
\hline 4 & $24 \mathrm{M}$ & 101 & Softball varus & 4 & 25 A. D & $\mathbf{N}$ & $\mathbf{N}$ & Fracture & $0 / 0$ & $0 / 0$ & $\mathbf{0} / \mathbf{0}$ & -0.25 & Yes & $\mathbf{0}$ & None \\
\hline 5 & $15 \mathrm{M}$ & 61 & Baseball valgus & s 5 & IH A, D & L-incomplete & $\mathbf{N}$ & $\mathbf{N}$ & $0 / 1$ & $0 / 1$ & $0 / 0$ & - & No & $2 \mathrm{ADL}$ & None \\
\hline 6 & $20 \mathrm{~F}$ & 84 & $\begin{array}{l}\text { Gym class } \\
\text { unknown }\end{array}$ & 12 & $25 \mathrm{~A}$ & $\mathrm{~N}$ & $\mathbf{N}$ & $\mathbf{N}$ & $0 / 0$ & $0 / 0$ & $0 / 0$ & 1.5 & No & $\mathbf{0}$ & None \\
\hline 7 & $28 \mathrm{M}$ & 65 & Work valgus & 7 & IH A, M & Med-incomplete & $\mathbf{N}$ & $\mathbf{N}$ & 0,0 & $0 / 0$ & $0 / 0$ & 1.25 & Yes & 0 & None \\
\hline 8 & $32 \mathrm{M}$ & 34 & $\begin{array}{l}\text { Baseball } \\
\text { jumping }\end{array}$ & 8 & $25 \mathrm{~A}, \mathrm{Px}$ & $\mathrm{N}$ & $\mathbf{N}$ & Fracture & $0 / 0$ & $0 / 0$ & $0 / 0$ & 4.0 & No & 0 & None \\
\hline 9 & $20 \mathrm{M}$ & 110 & $\begin{array}{l}\text { Football } \\
\text { running }\end{array}$ & 8 & $25 \mathrm{~A}$ & $\mathrm{~N}$ & $\mathbf{N}$ & Fissuring & $0 / 0$ & $0 / 0$ & $0 / 0$ & 1.0 & No & 0 & None \\
\hline 10 & $28 \mathrm{M}$ & 42 & $\begin{array}{l}\text { Football } \\
\text { contact }\end{array}$ & 45 & $25 \mathrm{~A}, \mathrm{Px}$ & $\begin{array}{l}\text { Med-incomplete } \\
\text { L-partial }\end{array}$ & $\begin{array}{l}\text { LFC } \\
\text { fracture }\end{array}$ & $\mathbf{N}$ & $1 / 1$ & $0 / 1 \#$ & $0 / 1$ & 6.25 & No & 1 recreational & None \\
\hline 11 & $17 \mathrm{M}$ & 97 & Soccer running & 14 & IH & L-incomplete & $\mathbf{N}$ & $\mathrm{N}$ & $0 / 0$ & $0 / 0$ & $0 / 0$ & 2.0 & Yes & 2 competitive & None \\
\hline 12 & $16 \mathrm{M}$ & 24 & Football valgus & s 9 & IH A. M & $\mathrm{N}$ & Softening & Softening & $0 / 0$ & $0 / 0$ & $0 / 0$ & - & No etc & 0 & None \\
\hline 13 & $19 \mathrm{M}$ & 93 & Football valgus & 55 & IHA. M & L-incomplete & $\mathbf{N}$ & Softening & $0 / 1 \#$ & $0 / 1 \#$ & $0 / 0$ & 2.25 & Yes & 0 & None \\
\hline 14 & $16 \mathrm{M}$ & 60 & Football twist & 11 & $25 \mathrm{~A}, \mathrm{D}$ & MM-total & $\mathbf{N}$ & $\mathbf{N}$ & $1 / 1$ & $1 / 1$ & $0 / 0$ & -2.50 & No & 0 & None \\
\hline 15 & $38 \mathrm{~F}$ & 33 & Tennis jumping & 839 & $25 \mathrm{~A}, \mathrm{M}$ & $\mathbf{N}$ & $\mathbf{N}$ & Softening & $1 / 1$ & $0 / 0$ & $1 / 0$ & -0.25 & No & I recreational & None \\
\hline 16 & $16 \mathrm{M}$ & 52 & Soccer valgus & 0 & $25 \mathrm{~A}, \mathrm{M}$ & Med-incomplete & $\mathbf{N}$ & Softening & $1 / 1$ & $0 / 0$ & $0 / 1$ & 0.75 & Yes & o & None \\
\hline 17 & $25 \mathrm{M}$ & 38 & Football varus & 16 & $25 \mathrm{~A}, \mathrm{M}$ & L.partial & $\begin{array}{l}\text { LFC } \\
\text { softening }\end{array}$ & Softening & $0 / 0$ & $0 / 0$ & $0 / 0$ & -0.50 & No & I ADL & None \\
\hline 18 & $25 \mathrm{M}$ & 78 & $\begin{array}{l}\text { Basketball } \\
\text { running }\end{array}$ & 37 & $50 \mathrm{~A}, \mathrm{M}$ & L-partial & $N$ & $N$ & $1 / 1$ & $1 / 1$ & $0 / 0$ & 2.25 & No & 2 recreational & None \\
\hline 19 & $17 \mathrm{M}$ & 84 & $\begin{array}{l}\text { Football } \\
\text { jumping }\end{array}$ & 0 & So Ps, Px & $N$ & $N$ & $N$ & $1 / 0$ & $0 / 0$ & $0 / 0$ & -0.75 & Yes & 5 competitive & $\begin{array}{l}\text { Partial medial } \\
\text { meniscectomy }\end{array}$ \\
\hline 20 & $23 \mathrm{M}$ & 37 & Work jumping & 2 & 50 A. Px & Med-incomplete & $N$ & $\mathbf{N}$ & $1 / 2 "$ & $1 / 2 \#$ & $0 / 0$ & - & Yes & I ADL & $\begin{array}{l}\mathrm{ACL} \\
\text { reconstruction }\end{array}$ \\
\hline 21 & $22 \mathrm{M}$ & 83 & $\begin{array}{l}\text { Basketball } \\
\text { jumping }\end{array}$ & 15 & 50 A. M & $N$ & $\mathbf{N}$ & Softening & $1 / 2$ & $1 / 2 \#$ & $0 / 0$ & - & Yes & 5 recreational & None \\
\hline 22 & $17 \mathrm{M}$ & 46 & $\begin{array}{l}\text { Basketball } \\
\text { falling }\end{array}$ & 9 & 50 A, Px & $N$ & $\mathbf{N}$ & $\mathbf{N}$ & $1 / 2$ & $1 / 2 \#$ & $0 / 0$ & 5.0 & Yes & 5 competitive & $\begin{array}{l}\text { ACL } \\
\text { reconstruction }\end{array}$ \\
\hline 23 & $26 M$ & 36 & $\begin{array}{l}\text { Non-athletic } \\
\text { varus }\end{array}$ & 12 & 50 & $\begin{array}{l}\text { Med-repaired } \\
\text { through } \\
\text { arthroscope }\end{array}$ & $\mathbf{N}$ & $\mathbf{N}$ & $1 / 1$ & $1 / 1$ & $0 / 0$ & - & No & $\mathbf{0}$ & None \\
\hline 24 & $24 M$ & 100 & Soccer contact & 6 & $50 \mathrm{~A}, \mathrm{M}$ & $\mathbf{N}$ & $N$ & $N$ & $0 / 1 \#$ & $0 / 1 \#$ & $0 / 1$ & - & Yes & I competitive & None \\
\hline 25 & $22 \mathrm{M}$ & 93 & Football valgus & s 3 & $\begin{array}{l}50 \mathrm{~A}, \mathrm{M} \\
\mathrm{Px}\end{array}$ & $\mathbf{N}$ & $\mathbf{N}$ & $\mathbf{N}$ & $0 / 0$ & $0 / 0$ & $0 / 0$ & - & No & 0 & None \\
\hline 26 & $22 \mathrm{M}$ & 31 & $\begin{array}{l}\text { Basketball } \\
\text { hyperextension }\end{array}$ & 18 & 75 Ant & Med-incomplete & $\mathbf{N}$ & $\mathbf{N}$ & $1 / 2 \#$ & $1 / 2 \#$ & $1 / 0$ & 6.0 & Yes & I competitive & $\begin{array}{l}\text { Arthroscopy- } \\
\text { absent ACL. Partial } \\
\text { medial and lateral } \\
\text { meniscectomy }\end{array}$ \\
\hline 27 & $34 \mathrm{M}$ & 32 & $\begin{array}{l}\text { Volleyball } \\
\text { valgus }\end{array}$ & 15 & 75 A. Px & $\begin{array}{l}\text { Med-repaired } \\
\text { through } \\
\text { arthroscope }\end{array}$ & $\begin{array}{l}\text { LFC } \\
\text { fracture }\end{array}$ & $\begin{array}{l}\text { Exposed } \\
\text { bone }\end{array}$ & $1 / 1$ & $1 / 1$ & $0 / 0$ & 2.0 & No & $4 \mathrm{ADL}$ & None \\
\hline 28 & $19 M$ & 87 & $\begin{array}{l}\text { Volleyball } \\
\text { hyperextension }\end{array}$ & 56 & 75 & Med-total & $N$ & $N$ & $1 / 1$ & $1 / 1$ & $1 / 1$ & 7.25 & No & 6 recreational & None \\
\hline 29 & $23 \mathrm{M}$ & 64 & $\begin{array}{l}\text { Wrestling } \\
\text { contact }\end{array}$ & 10 & $75 \mathrm{~A}, \mathrm{M}$ & L-partial & $\begin{array}{l}\text { LFC } \\
\text { fissures }\end{array}$ & $\mathrm{N}$ & $1 / 1$ & $1 / 2 \#$ & $1 / 1$ & 5.75 & Yes & $\begin{array}{l}3 \text { light } \\
\text { recreational }\end{array}$ & None \\
\hline 30 & $26 \mathrm{~F}$ & 96 & Softball valgus & 8 & 75 A. M & Med-incomplete & $\begin{array}{l}\text { MTP } \\
\text { fissures }\end{array}$ & $N$ & $1 / 2 \#$ & $1 / 1$ & $0 / 0$ & 7.0 & Yes & I recreational & $\begin{array}{l}\text { Partial medial } \\
\text { meniscectomy }\end{array}$ \\
\hline 31 & $15 \mathrm{M}$ & 80 & $\begin{array}{l}\text { Football } \\
\text { contact }\end{array}$ & 25 & $\begin{array}{l}75 \mathrm{~A} \\
\mathrm{M}, \mathrm{Px}\end{array}$ & $\mathbf{N}$ & $\mathbf{N}$ & $\mathbf{N}$ & $1 / 2 \#$ & $1 / 2 \#$ & $0 / 0$ & 5.25 & No & $\begin{array}{l}\text { I major } \\
\text { recreational }\end{array}$ & None \\
\hline 32 & $15 \mathrm{M}$ & 56 & Football twist & 12 & $\begin{array}{l}75 \mathrm{~A} \\
\text { M. D }\end{array}$ & $N$ & $N$ & $\mathbf{N}$ & $1 / 1$ & $1 / 24$ & $0 / 0$ & - & Yes & I competitive & $\begin{array}{l}\text { Arthroscopy - } \\
\text { absent ACL }\end{array}$ \\
\hline
\end{tabular}

- A anterior fibre: Ps posterior fibre: Px proximal one-third: $M$ middle one-third: D distal one-third: $1 \mathrm{H}$ grossly observable haemorrhage: 25 haemorrhage and tear of fibre equal to or less than estimated $25^{\circ}$ of the ligament: 50 tear of estimated $50^{\circ}$ of the ligament: 75 tear of estimated $75 \%$ of the ligament

$+N$ normal: L lateral tear: Med medial tear

+ LFC lateral femoral condyle: MTP medial tibial plateau

$\$$ Initial assessment under anaesthesia. Ligamentous stability: 0 equal to normal side, I one grade increase, 2 two grade increase, \# conversion to ACL deficient 
third, or distal); the fibre bundles in relationship to the tibia (anterior or posterior); and the estimated amount of gross tearing that could be observed - one-fourth or less, one-half, or three-fourths. This latter estimate was not intended to define the exact amount of damage since the ligament may sustain microscopic injury without gross disruption (Noyes, DeLucas and Torvik 1974). We

Table II. Sports activities scale

\begin{tabular}{|c|c|}
\hline & Points \\
\hline $\begin{array}{l}\text { Level I (participates } 4 \text { to } 7 \text { days per week) } \\
\text { Jumping, hard pivoting, cutting } \\
\text { (basketball, volleyball, football, gymnastics, soccer) } \\
\text { Running, twisting, turning } \\
\text { (tennis, racquetball, handball, baseball, ice hockey, } \\
\text { feld hockey, skiing, wrestling) } \\
\text { No running, twisting, jumping } \\
\text { (cycling, swimming) }\end{array}$ & 100 \\
\hline $\begin{array}{l}\text { Level II (participates } 1 \text { to } 3 \text { days per week) } \\
\text { Jumping, hard pivoting, cutting } \\
\text { (basketball, volleyball, football, gymnastics, soccer) } \\
\text { Running, twisting, turning } \\
\text { (tennis, racquetball, handball, baseball, ice hockey, } \\
\text { feld hockey, skiing, wrestling) } \\
\text { No running, twisting, jumping } \\
\text { (cycling, swimming) }\end{array}$ & $\begin{array}{l}85 \\
80\end{array}$ \\
\hline $\begin{array}{l}\text { Level III (participates I to } 3 \text { times each month) } \\
\text { Jumping, hard pivoting, cutting } \\
\text { (basketball, volleyball, football, gymnastics, soccer) } \\
\text { Running, twisting, turning } \\
\text { (tennis, racquetball, handball, baseball, ice hockey, } \\
\text { field hockey, skiing, wrestling) } \\
\text { No running, twisting, jumping } \\
\text { (cycling, swimming) }\end{array}$ & 65 \\
\hline $\begin{array}{l}\text { Level IV (no sports) } \\
\text { Activities of daily living without problems } \\
\text { Activities of daily living with moderate problems } \\
\text { Activities of daily living with severe problems - } \\
\text { crutches, full disability }\end{array}$ & $\begin{array}{r}40 \\
20 \\
0\end{array}$ \\
\hline
\end{tabular}

Table III. Grading scales for limitations of function

\begin{tabular}{|c|c|c|c|}
\hline \multicolumn{3}{|c|}{ Points } & Points \\
\hline $\begin{array}{l}\text { Activities of daily living } \\
\text { I Walking }\end{array}$ & & $\begin{array}{l}\text { Sports activities } \\
\text { I Straight running }\end{array}$ & \\
\hline $\begin{array}{l}\text { Normal, unlimited } \\
\text { Some limitations } \\
\text { Smooth surface OK up to } 1 \text { mile } \\
\text { Only } 3 \text { to } 4 \text { blocks possible } \\
\text { Less than one block, cane, crutch }\end{array}$ & $\begin{array}{r}50 \\
40 \\
30 \\
20 \\
0\end{array}$ & $\begin{array}{l}\text { Fully competitive } \\
\text { Some limitations, guarding } \\
\text { Run half-speed, definite limitations } \\
\text { Only I to } 2 \text { blocks possible } \\
\text { Not able }\end{array}$ & $\begin{array}{r}100 \\
80 \\
70 \\
60\end{array}$ \\
\hline 2 Stairs & \multicolumn{3}{|c|}{2 Short sprints, stops and starts } \\
\hline $\begin{array}{l}\text { Normal, unlimited } \\
\text { Some limitations } \\
\text { Only } 20 \text { to } 30 \text { steps possible } \\
\text { Only } 10 \text { to } 19 \text { steps possible } \\
\text { Only I to } 9 \text { steps possible }\end{array}$ & $\begin{array}{r}50 \\
40 \\
30 \\
20 \\
0\end{array}$ & $\begin{array}{l}\text { Fully competitive } \\
\text { Some limitations, guarding } \\
\text { Run half-speed, definite limitations } \\
\text { Only able to do a few per game } \\
\text { Not able }\end{array}$ & \\
\hline 3 Squatting/kneeling & \multicolumn{3}{|c|}{3 Jumping/landing on affected leg } \\
\hline $\begin{array}{l}\text { Normal, unlimited } \\
\text { Some limitations } \\
\text { Only } 6 \text { to } 10 \text { possible } \\
\text { Only } 0 \text { to } 5 \text { possible } \\
\text { Not able }\end{array}$ & $\begin{array}{r}50 \\
40 \\
30 \\
20 \\
0\end{array}$ & $\begin{array}{l}\text { Fully competitive } \\
\text { Some limitations, guarding } \\
\text { Definite limitations, half speed } \\
\text { Affects all sports, constantly guards } \\
\text { Not able }\end{array}$ & \\
\hline & \multicolumn{3}{|c|}{4 Hard twists/cuts/pivots on affected leg } \\
\hline & & $\begin{array}{l}\text { Fully competitive } \\
\text { Some limitations, guarding } \\
\text { Definite limitations, avoids at times } \\
\text { Affects all sports, constantly guards } \\
\text { Not able }\end{array}$ & $\begin{array}{r}100 \\
80 \\
70 \\
60 \\
0\end{array}$ \\
\hline
\end{tabular}

recognised that it is sometimes difficult to estimate the amount of tearing in this way, but direct visualisation of the gross disruption remains the only means available.

In 17 knees (cases 1 to 17, Table I) we estimated one-fourth or less of tearing (interstitial haemorrhage within and about the ligament fibres in six, haemorrhage plus partial tearing in 11). Eight knees (cases 18 to 25) had tearing of approximately one-half of the ligament. Seven knees (cases 26 to 32) had tearing of three-fourths of the ligament, but the remaining portion still resisted anterior tibial translation at arthroscopy.

Meniscal tears. There was a tear of one or both menisci in 17 of the 32 knees (53\%) (Table I), involving the medial meniscus in nine, the lateral meniscus in seven, and both menisci in one. Surgery for the meniscal tear was performed in eight cases $(25 \%)$.

Articular cartilage. We used the criteria of Outerbridge (1961). Eleven knees (34\%) had lesions of the patella; seven with grade I changes, one with grade II, and three with grade IV. Two patients had chondral fractures of the patella. Four knees showed lesions of the lateral femoral condyle: one with grade I changes, one with grade II and two with chondral fractures.

Initial treatment and rehabilitation. All patients had a standard rehabilitation programme designed to protect the partial tear. We used a '4-4-4-4' programme, which allows a graduated return to activities over 16 weeks. During the first four weeks the patient is allowed partial weight-bearing with crutches. A cast was used in 16 cases and a soft compression dressing and/or splint in the others. The second four-week period involves increased weight-bearing, weaning from crutches, and resumption of walking. The third four-week period includes graduated strengthening exercises, but we do not allow terminal quadriceps extension exercises, heavy weights, or the use of high-resistance exercise machines in the $0^{\circ}$ to $30^{\circ}$ knee flexion range in order to diminish forces potentially injurious to the ACL (Paulos et al 1981; Grood et al 1984). During the final four-week period there is gradual return to athletics with running and sporting activities at first of low intensity.

Follow-up evaluation. Symptoms of pain, swelling, and giving-way were recorded in relation to the activity level (Noyes et al 1983a). The objective portion of the rating system is composed of the physical examination of the knee (Noyes et al 1983), and the classification of ligament defects and joint subluxations (Noyes and Grood 1987). A sports activity rating scale ranging from level I (frequent strenuous sport) to level IV (no sport) was used to analyse the level of sports participation (Table II), and activities of both daily living and sport were analysed according to a five-level gradient of difficulty (Table III). Compliance to the prescribed exercise programme was assessed by questionnaire (Noyes et al 1983a).

Problems with sport were assessed by asking the patients to estimate their ability to perform a strenuous, moderate, or light intensity sport for one hour without 


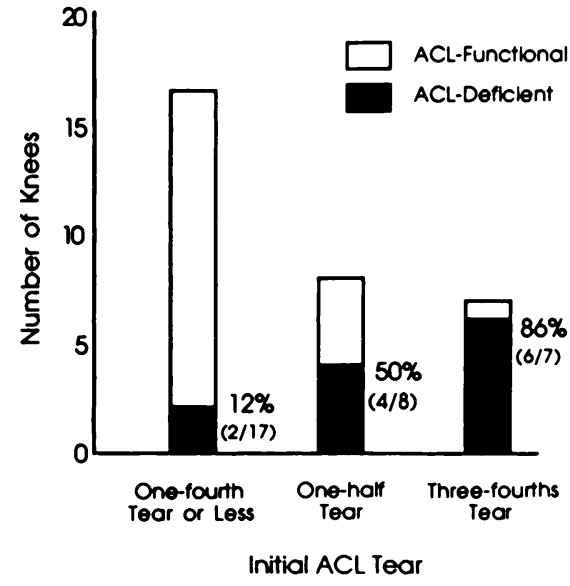

Fig. 1

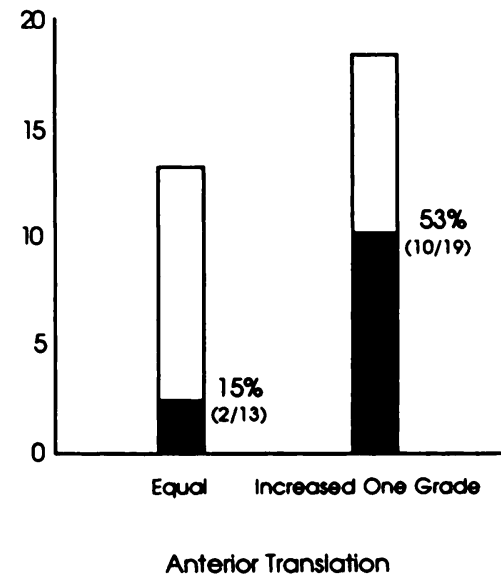

Fig. 2

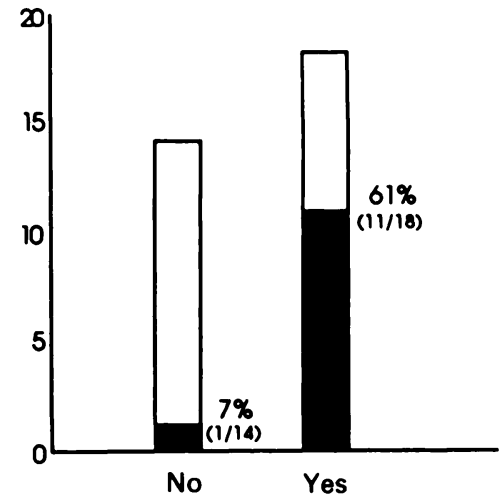

Giving-Way Reinjury

Fig. 3

The relationship between the initial estimate of the extent of the tear and the function of the anterior cruciate ligament (Fig. 1). The relationship between the inital grading of anterior translation (Fig. 2) and the incidence of a re-injury with giving way (Fig. 3) to the development of ACL deficiency.

guarding or limitations. This method provides a common denominator and reduces the bias of patients participating in different types of sport at different intensities.

Criteria for ACL deficiency. We defined an ACL-deficient knee as having positive pivot shift and Lachman tests (grade III) (Noyes and Grood 1987) and a KT-1000 arthrometer reading showing $5 \mathrm{~mm}$ or more increased anteroposterior translation compared with the opposite normal knee. Twelve of the 32 knees had unequivocally positive pivot shift tests and/or increased arthrometer measurements; they were classified as having progressed to complete ACL deficiency. In designing this study, we confronted the possibility of failing to detect complete ACL deficiency at follow-up in knees whose secondary ligamentous restraints allowed only minimally increased anterior translation. We followed criteria established by Daniel et al (1985) and in our previous reports (Noyes et al 1983a,b) to exclude such knees. Two knees (cases 2 and 8) had slightly increased anteroposterior translation (3.75 $\mathrm{mm}$ and $4.0 \mathrm{~mm}$ on KT-1000) but demonstrated a negative pivot shift phenomenon. We recorded these knees as still having a functional anterior cruciate ligament. The average difference for knees (injured minus uninjured) which were classified as having a functional ACL was $0.9 \mathrm{~mm}$ (s.d. 1.8 , range -2.5 to $4.0 \mathrm{~mm}$ ). Those knees at follow-up classified as ACL-deficient had an average difference of $5.6 \mathrm{~mm}$ (s.d. 1.6, range 2.25 to $7.25 \mathrm{~mm}$ ). The difference between the two groups was statistically significant $(\mathrm{p}<0.001)$.

\section{RESULTS}

The time from initial injury to final follow-up averaged 67 months (range 24 to 110$)$. Twelve of 32 knees $(38 \%)$ had progressed to ACL deficiency by the criteria we established. The average follow-up time for the ACLdeficient group was 68 months (range 31 to 105) and for the ACL-functional group, 65 months (range 24 to 110 ).
We found a statistically significant relationship $(p<0.01)$ for progression to ACL deficiency for three factors:

1) the amount of estimated ACL tearing at initial arthroscopy (Fig. 1);

2) an increase in anterior translation, although subtle, on the initial examination (Fig. 2), and

3 ) the subsequent occurrence of a giving-way re-injury (Fig. 3).

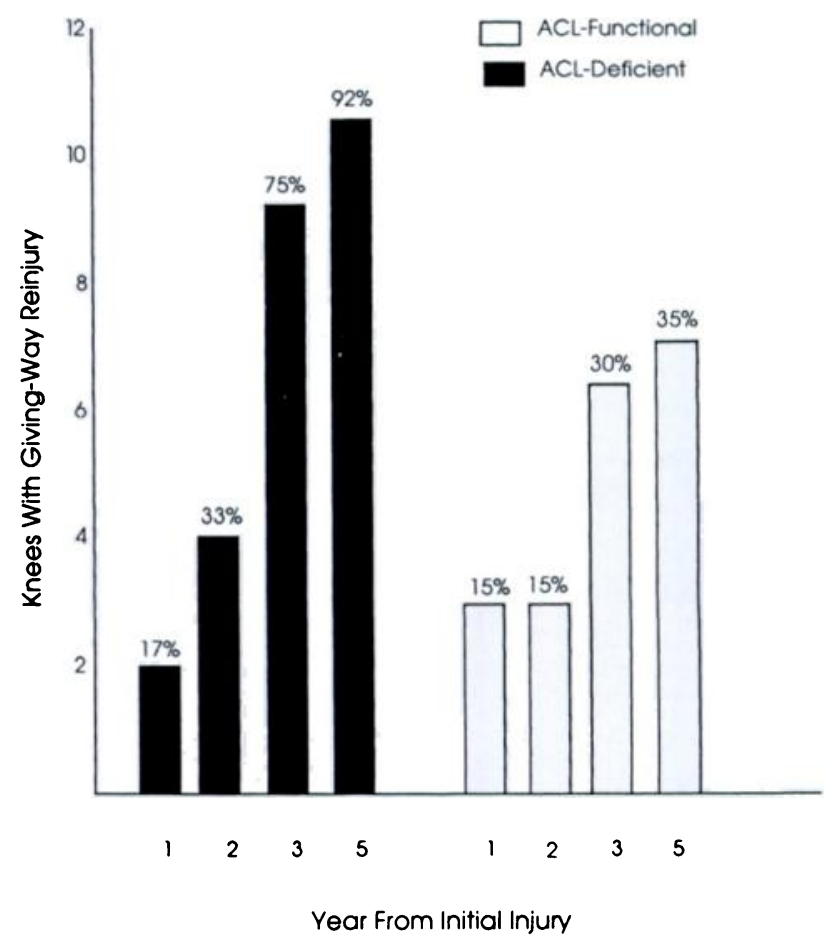

Fig. 4

Cumulative numbers and percentages of re-injury episodes with givingway in functional and deficient groups related to years from the initial injury. 


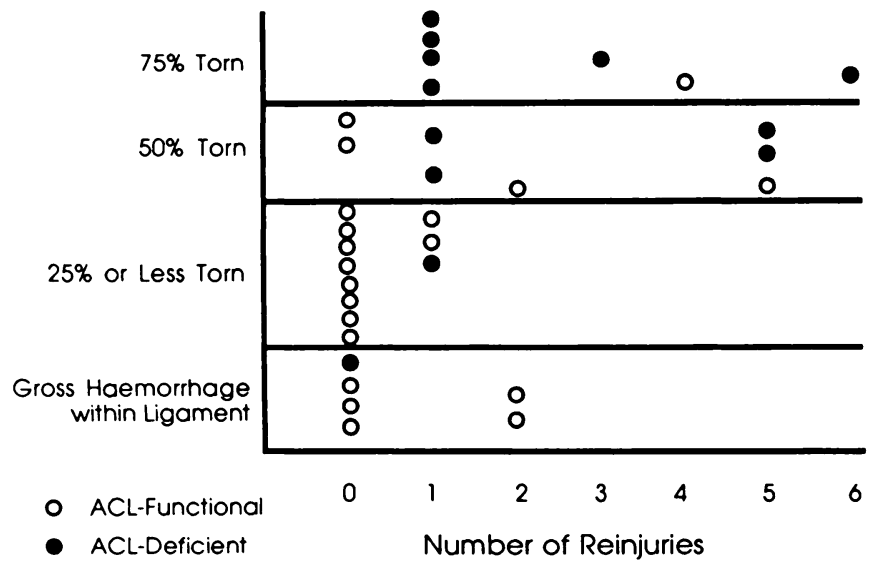

Fig. 5

The relationship between the estimated extent of the tear and the number of re-injuries.

There was no statistically significant relationship between progression to ACL deficiency and meniscectomy, articular cartilage damage, plaster immobilisation, compliance to the rehabilitation programme, work activity level after injury, the level of athletics that the patient resumed, maintenance of an exercise programme or the importance of athletics to the patient.

We analysed the length of time from the initial injury to the first significant giving-way re-injury for both deficient and functional knees (Fig. 4). Most first reinjuries occurred two years or more after the initial injury, and the average number was statistically higher for the ACL-deficient group (2.2; range 0 to 6 ) than for the ACLfunctional group $(0.85$; range 0 to 5$)(t$-test, $\mathrm{p}<0.0001)$. Nine patients had one re-injury, five had from two to four, and four patients had five or more re-injuries. We could not determine when the progression to an ACLdeficient knee had occurred, that is, before or after a reinjury.

Re-injuries occurred during level I sports activity (see Table II) in six cases (33\%), level II activity in seven $(39 \%)$, level III activity in one $(6 \%)$, and during level IV activity or work in four cases $(22 \%)$. There was no statistical relationship between the two subgroups, ACLfunctional and ACL-deficient, and the type of activity in which the re-injuries occurred.

Of the 17 knees with one-fourth or less of the ligament torn, five sustained re-injuries $(29 \%)$ and two progressed to ACL deficiency. Of the eight knees with one-half torn, six sustained re-injuries $(75 \%)$ and four became ACL deficient. All of the seven knees with threefourths tearing sustained a re-injury; all but one became ACL deficient (Fig. 5).

Symptom rating. The mean values and standard deviations are given in Table IV. Before injury, the knee scores were all normal or in the high $90 \%$ range. After injury, we found statistically significant decreases in the mean scores for pain, swelling, giving-way, and the overall subjective average for both subgroups. In Figure 6, the results are scaled to show the highest symptom-free level of activity that is possible. For example, in the pain category, the ACL-deficient group score of $67 \%$ indicates that these patients were unable to participate beyond level III (Table II) without experiencing significant pain. Patients whose ACL remained functional were able to participate, symptom free, at level II, although they had some symptoms with level I activities.

Functional rating. Table IV also shows the mean values for daily living and sport activities. The decrease after injury in all functional categories (except walking) is statistically significant for both the ACL-functional and ACL-deficient groups $(\mathrm{p}<0.001)$. The parameters are scaled in Figure 6 to allow comparisons. Activities of daily living score up to a maximum of 50 points and the sports activities score up to a maximum of 100 points. Overall, the ACL-functional group were less able to perform strenuous sports; however, they were able to perform level II activities without limitation. The ACLdeficient group showed further limitation of ability for sport.

Sports and work activity rating. Statistical analysis showed that, before injury, there was no difference in the sports activity rating of ACL-deficient and ACL-functional subgroups, allowing a valid comparison of sports activities after injury. At follow-up, both subgroups showed major decreases in the intensity level for sports participation (Table IV). Before their knee injury, nearly all patients were able to participate in level I sports activities without problems, but at follow-up both subgroups had problems.

The sports rating is shown in Figure 7 to allow comparisons. Work activities before and after injury, however, showed no statistical difference between the subgroups.

Figure 8 shows an important subgroup which deviates from the general trend of decreasing participation in sports and included $58 \%$ of the patients in the ACL-deficient group and $20 \%$ of those in the ACLfunctional group. These patients did not modify their activities despite having moderate or significant problems at their current level of sport and were categorised as 'knee abusers' since they had continued despite significant problems (Noyes et al 1983b).

\section{DISCUSSION}

Both partial and complete ACL tears produce a pop at the time of injury, an acute haemarthrosis within hours, and the inability in most patients to continue sport immediately after the injury (McDaniel 1976; Noyes et al 1980; Monaco et al 1982; Farquharson-Roberts and Osborne 1983). Two subgroups of patients with partial tears require emphasis. One includes patients with subsynovial rupture of only a few fibres, small or absent 


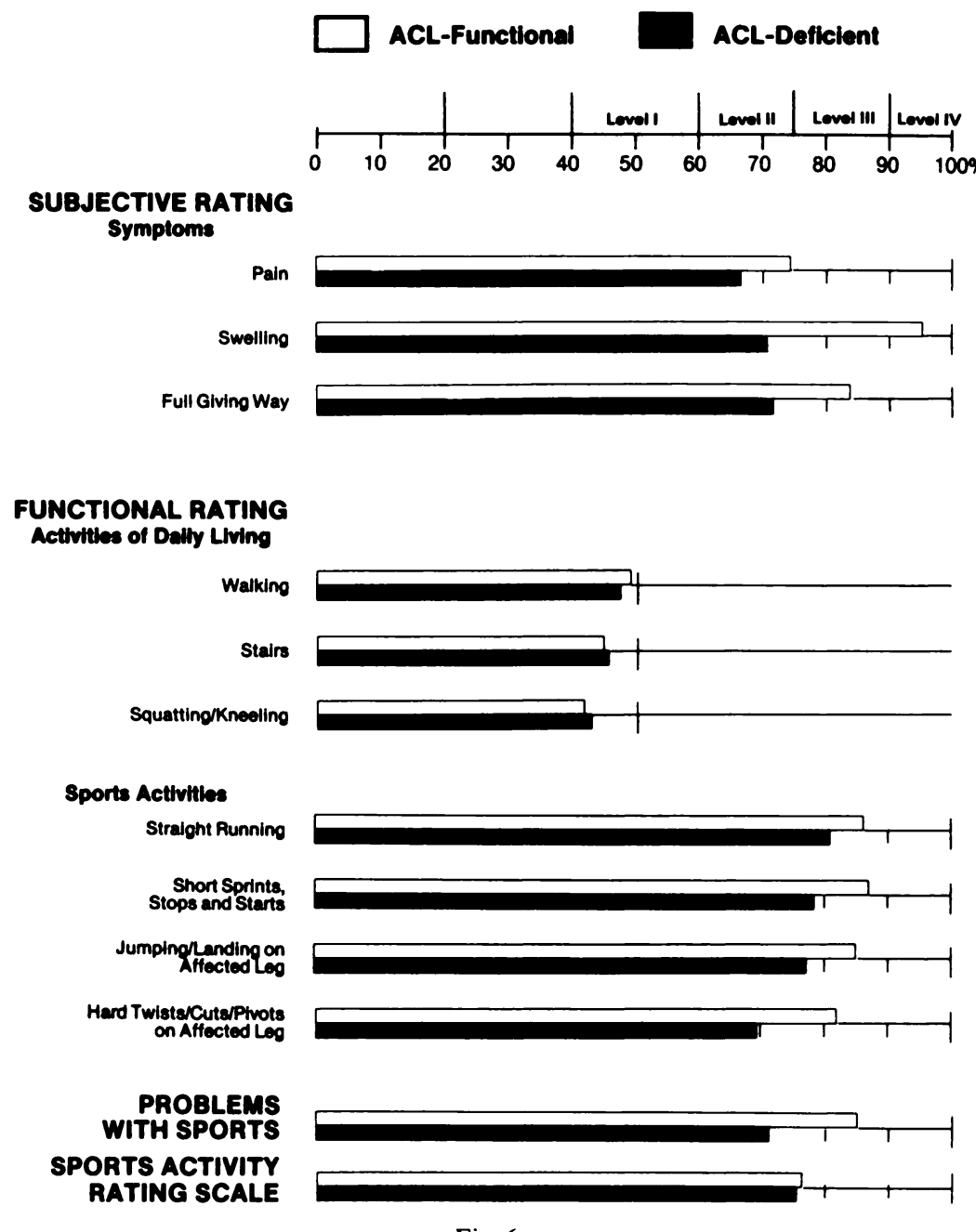

Fig. 6

Bar chart for the subjective and functional ratings in Table IV.

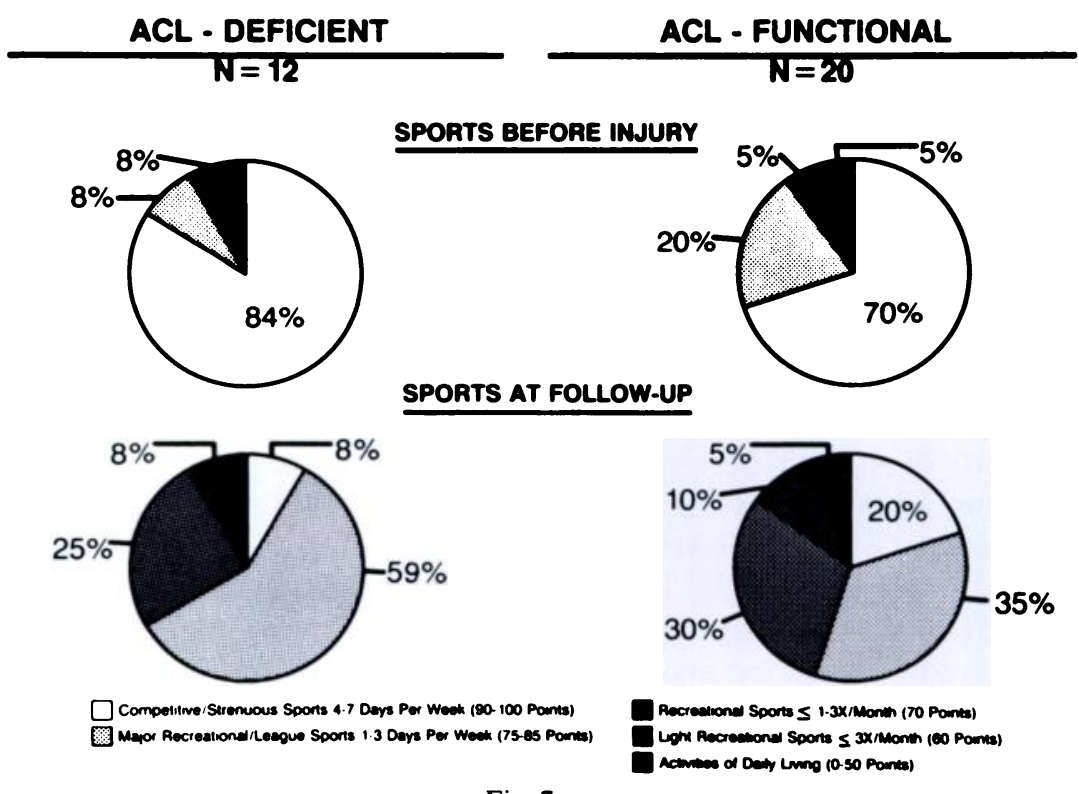

Fig. 7

Sports activity levels before injury and at follow-up for ACL-functional and ACLdeficient knees. 
Table IV. Symptoms and function level scores (mean \pm s.d.)

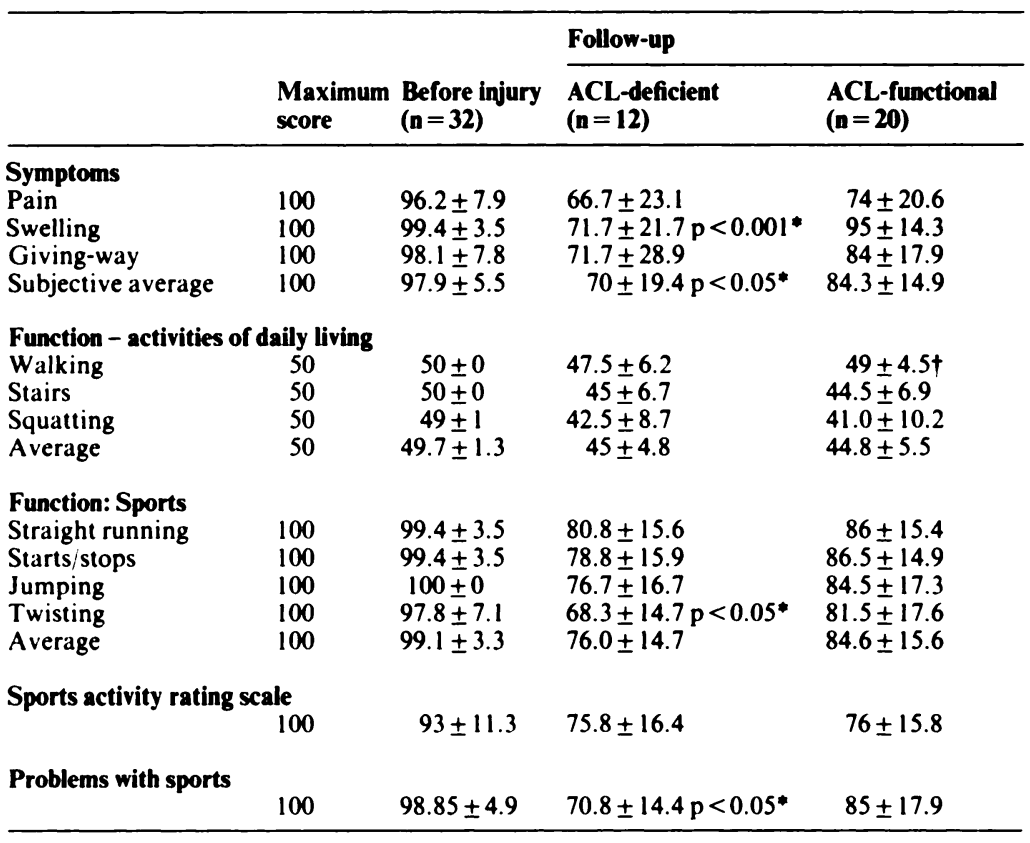

* statistical significance of difference between ACL-deficient and ACL-functional results $\dagger$ all follow-up results except this differed from the pre-injury level with a significance of $\mathrm{p}<0.001$

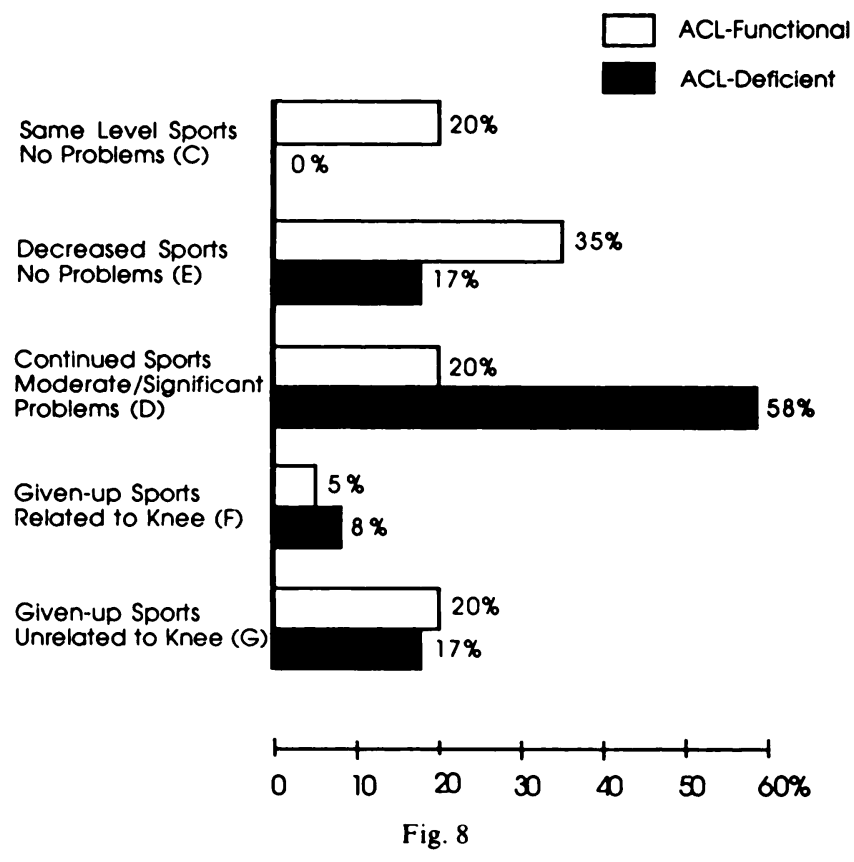

Change in sporting activity from pre-injury level related to $\mathrm{ACL}$ function.

haemarthrosis, and minimal limitation of function. We suspect that subclinical tearing may occur more frequently than is realised or diagnosed.

In the second, more important subgroup, the clinical presentation is mistaken for a meniscus tear, because of the history of twisting injury, the loss of full knee extension, a small or negligible joint effusion, and no increased tibial translation (McDaniel 1976; Monaco et al 1982; Farquharson-Roberts and Osborne 1983).

With both partial and complete ACL tears there is a high incidence of associated damage to other knee structures: $53 \%$ of partial ACL tears in our series had associated meniscus damage, and repair or partial meniscectomy was performed in $25 \%$. However, this frequency is less than that found with complete ACL tears (Liljedahl et al 1965; McDaniel and Dameron 1980; Noyes et al 1980; DeHaven 1983). A chondral fracture or other damage to the articular cartilage was found in a smaller percentage of knees ( $13 \%)$.

We have previously discussed in detail the indications for examination under anaesthesia in cases of acute haemarthrosis (Noyes et al 1974, 1980, 1983b). Not all knees with an acute haemarthrosis require arthroscopy; we have been able to avoid this in many cases by repeating the clinical examination after the acute symptoms had subsided, and in certain knees, obtaining an MRI scan. Nevertheless, if the diagnosis is uncertain and additional information is needed to determine the proper treatment, arthroscopy is required to establish the extent of damage and allow rational treatment.

We consider that arthroscopy is indicated in:

1) competitive or recreationally-active patients who wish to resume full athletic activities soon and need an exact diagnosis;

2) patients whose activity and athletic life-style dictate that surgical management would be required for an acute anterior cruciate tear; and

3) cases in which a meniscus tear is diagnosed. 
There are other indications, to be decided on a case-bycase basis following the recommendations which we and others have made (Noyes et al 1980; DeHaven 1983).

Our study indicates that tears estimated to involve one-fourth or less of the ligament have a reasonably good prognosis, but we still advise patients that the chance of a re-injury is higher than normal during athletic activities. We direct initial treatment towards protecting the injured ligament, hoping that damaged fibres will heal, and advising patients to return to athletics only after completing a thorough rehabilitation programme which includes retraining in neuromuscular and skill factors where strenuous athletics are involved.

Tears estimated to involve one-half of the ligament progressed to ACL deficiency in $50 \%$ of cases, and we believe that a guarded prognosis should be clearly stated to the patient. More important, the incidence of reinjuries in this group reached $75 \%$, often not occurring until two or more years later.

Knees with tearing of three-fourths of the ligament progressed to ACL deficiency in all but one case. We have previously published our activity modification and rehabilitation programme for such knees and have stressed the need to prevent the re-injuries which would further damage the joint (Noyes et al 1983a,b).

Our prognosis for partial ACL tears does not agree with one recent study. Odensten et al (1985) reported 21 patients with partial tears followed for an average of six years. Only three knees $(14 \%)$ became ACL deficient. These authors used a knee function scoring system in which the mean score at follow-up for all knees was 93 points out of a total of 100 . All knees were classified as good or excellent, including the three that had become ACL deficient.

It is impossible to decide with certainty the length of time that a partial ACL tear should be protected before resuming athletic activities. We found no benefit from plaster immobilisation over partial splinting with early movement, and still believe that grossly disrupted ACL fibres which are not in continuity do not heal. In our experience, disrupted fibres are either re-absorbed, remain in the intercondylar notch but are non-functional, or re-attach to the synovial tissues about the posterior cruciate ligament. We therefore question whether the healing of partial tears can restore the functional properties of the ligament and we advise that our athletically-active patients should be examined every six months for five years after their injury. These reexaminations enable us to assess whether or not there has been a re-injury and to assess the function of the ligament. It also allows the physician to counsel the patient and recommend changes in activity where progression has occurred.

\section{Conclusions.}

1. The progression of a partial tear to complete ACL deficiency is related to the estimated extent of the original tear $(p<0.01)$, to the presence of any increase, however subtle, of anterior tibial translation $(p=0.01)$, and the occurrence of subsequent re-injury with giving-way $(\mathrm{p}<0.01)$.

2. Partial tears involving one-fourth or less of the ligament infrequently progress $(12 \%)$, whereas tears of onehalf or three-fourths do so more often $(50 \%$ and $86 \%$, respectively).

3. A giving-way re-injury was frequent (56\%) and more common than is normal in athletic activities. This suggests that knees with partial tears are either more prone to subsequent injury or were at greater risk for knee injury in the first place.

4. Re-injury with giving-way was often seen two or more years after the initial injury: this indicates the need to follow patients for an extended period of time.

5. Patients after partial tears that did not progress to ACL deficiency were not entirely normal; about one-half had symptoms and functional limitations in competitive or strenuous sports.

6. Most patients whose tears had progressed to ACL deficiency were limited in performing twisting, cutting, pivoting, jumping, and starting and stopping.

7. In all, $58 \%$ of the ACL-deficient group and $20 \%$ of the ACL-functional group continued to participate in athletics despite moderate to significant problems. This shows the need for additional educational efforts to reduce the risk of future osteoarthritis in these patients.

No benefits in any form have been received or will be received from a commercial party related directly or indirectly to the subject of this article.

\section{REFERENCES}

Bassett FH III. Concomitant injury to the lateral meniscus and anterior cruciate ligament in athletes. J Bone Joint Surg [Am] 1972;54A : 1342-3.

Daniel DM, Stone ML, Sachs R, Malcom L. Instrumented measurement of anterior knee laxity in patients with acute anterior cruciate ligament disruption. Am J Sports Med 1985;13:401-7.

DeHaven KE. Arthroscopy in the diagnosis and management of the anterior cruciate ligament deficient knee. Clin Orthop 1983;172: 52-6.

Farquharson-Roberts MA, Osborne AH. Partial rupture of the anterior cruciate ligament of the knee. J Bone Joint Surg [Br] 1983;65B:32-4.

Grood ES, Suntay WJ, Noyes FR, Butler DL. Biomechanics of the knee-extension exercise: effect of cutting the anterior cruciate ligament. J Bone Joint Surg [Am] 1984;66-A :725-34.

Liljedahl S-O, Lindvall N, Wetterfors J. Early diagnosis and treatment of acute ruptures of the anterior cruciate ligament: a clinical and arthrographic study of forty-eight cases. J Bone Joint Surg [Am] 1965;47-A:1503-13.

Lucie RS, Wiedel JD, Messner DG. The acute pivot shift: clinical correlation. Am J Sports Med 1984;12:189-91.

McDaniel WJ Jr. Isolated partial tear of the anterior cruciate ligament. Clin Orthop 1976;1 15:209-12.

McDaniel WJ Jr, Dameron TB Jr. Untreated ruptures of the anterior cruciate ligament: a follow-up study. J Bone Joint Surg [Am] $1980 ; 62-A: 696-705$ 
McDaniel WJ Jr, Dameron TB Jr. The untreated anterior cruciate ligament rupture. Clin Orthop 1983;172:158-63.

Monaco BR, Noble HB, Bachman DC. Incomplete tears of the anterior cruciate ligament and knee locking. $J A M A$ 1982;247:1582-4.

Noyes FR, Bassett RW, Grood ES, Butler DL. Arthroscopy in acute traumatic hemarthrosis of the knee: incidence of anterior cruciate tears and other injuries. J Bone Joint Surg [Am] 1980;62-A: $687-95$

Noyes FR, DeLucas JL, Torvik PJ. Biomechanics of anterior cruciate ligament failure: an analysis of strain-rate sensitivity and mechanisms of failure in primates. J Bone Joint Surg [Am] 1974;56A :236-53.

Noyes FR, Grood ES. Classification of ligament injuries: why an anterolateral laxity or anteromedial laxity is not a diagnostic entity. In: Griffin PP, ed. Instructional course lectures. Vol. 36. St. Louis, etc: CV Mosby Co, 1987:185-200.
Noyes FR, Matthews DS, Mooar PA, Grood ES. The symptomatic anterior cruciate-deficient knee. Part II. The results of rehabilitation, activity modification and counseling in functional disability. $J$ Bone Joint Surg [ Am] 1983a ;65-A :163-74.

Noyes FR, Mooar PA, Matthews DS, Butler DL. The symptomatic anterior cruciate-deficient knee. Part $I$. The long-term functional disability in athletically active individuals. J Bone Joint Surg [ Am] $1983 b ; 65-A: 154-62$.

Odensten M, Lysholm J, Gillquist J. The course of partial anterior cruciate ligament ruptures. Am J Sports Med 1985;13:183-6.

Outerbridge RE. The etiology of chondromalacia patellae. J Bone Joint Surg [Br] $1961 ; 43-B: 752-7$.

Paulos L, Noyes FR, Grood E, Butler DL. Knee rehabilitation after anterior cruciate ligament reconstruction and repair. Am J Sports Med $1981: 9: 140-9$. 